\title{
Investigation of novel material for effective photodegradation of bezafibrate in aqueous samples
}

\author{
Elżbieta Regulska • Joanna Karpińska
}

Received: 27 June 2013 / Accepted: 5 December 2013 / Published online: 8 January 2014

(C) The Author(s) 2014. This article is published with open access at Springerlink.com

\begin{abstract}
A novel composite with an enhanced photocatalytic activity was prepared and applied to study the removal of bezafibrate (BZF), a hypolypemic pharmaceutical, from an aqueous environment. For the enhancement of titanium dioxide photoactivity a fullerene derivative, 2-(ferrocenyl) fulleropyrrolidine $\left(\mathrm{FcC}_{60}\right)$, was synthesized and applied. $\mathrm{Ob}-$ tained composite was found to show a higher catalytic activity than pristine $\mathrm{TiO}_{2}$. Therefore, high hopes are set in composites that are based on carbonaceous nanomaterials and $\mathrm{TiO}_{2}$ as a new efficient photocatalysts.
\end{abstract}

Keywords Bezafibrate $\cdot$ Fullerene $\cdot$ Heterogeneous photocatalysis $\cdot$ Nanocomposite $\cdot$ Titanium dioxide

\section{Introduction}

Nowadays an occurrence of pharmaceuticals in the aqueous environment is regarded as a serious ecological problem. A variety of drugs were found in the following samples: sewagetreatment plant effluents (Hirsch et al. 1999), surface water (Hirsch et al. 1999; Ternes 1998; Calamari et al. 2003), seawater (Calamari et al. 2003), groundwater (Godfrey et al. 2007) and even in drinking water (Zwiener 2007). Pharmaceuticals are commonly excreted in an unchanged form and/or as metabolites in urine and faeces and discharged into domestic wastewaters continuously. Among innumerable amount of pharmaceuticals dumped into sewage system, bezafibrate (BZF) is classified as persistent contaminant. It is excreted as a parent compound for

Responsible editor: Philippe Garrigues

E. Regulska $\cdot$ J. Karpińska $(\bowtie)$

Department of General and Inorganic Chemistry,

Institute of Chemistry, University of Bialystok, Hurtowa 1,

15-399 Bialystok, Poland

e-mail: joasia@uwb.edu.pl about $50 \%$ (Castiglioni et al. 2005). Bezafibrate (2-(4-\{2-[(4chlorophenyl)formamido]ethyl $\}$ phenoxy)-2-methylpropanoic acid, BZF, Scheme 1), a blood-lipid-lowering agent, is widely used in the treatment of lipidemic diseases such as hypercholesterolemia and hypertriglyceridemia and to prevent heart attack (Weston et al. 2009). Due to the fact that BZF belongs to the most frequently prescribed drugs, it was proved to be ubiquitous in surface water and wastewater (Nikolaou et al. 2007). It was detected in concentrations ranging from $27 \mathrm{ng} / \mathrm{L}$ in drinking water (Ternes 2006), 0.1-0.15 $\mu \mathrm{g} / \mathrm{L}$ in large rivers (Ternes 2006; Kosma et al. 2007), 0.5-1.9 $\mu \mathrm{g} / \mathrm{L}$ in small streams (Ternes 2006), $3.1 \mu \mathrm{g} / \mathrm{L}$ in surface water (Weston et al. 2009) up to $4.6 \mu \mathrm{g} / \mathrm{L}$ level in sewage treatment plant effluents (Weston et al. 2009).

Hence, it is important to estimate efficient methods of BZF removal from a natural aqueous environment. Kinetic studies and identification of degradation products are also of a great concern. Accordingly, those issues were a matter of investigations presented in this paper.

A series of attempts were made in order to adequately remove BZF from natural aqueous samples. They included utilization of flocculation (Ternes et al. 2002), ozonation (Dantasa et al. 2007), filtration with granular activated carbon (Ternes et al. 2002), biodegradation (Kunkel and Radke 2008) and photolysis (Razavi et al. 2009). However, none of them seemed to be sufficiently efficient. Therefore, a huge potential lies in the application of heterogeneous photocatalysis (Lambropoulou et al. 2008). This process has a huge potential as a new route of destruction of organic as well as inorganic hazardous materials (Kabra et al. 2004). Photocatalytic degradation involves a photocatalyst presence. This role is mostly fulfilled by transition metal oxide semiconductors, among which titanium dioxide $\left(\mathrm{TiO}_{2}\right)$ is one of the most widely used. Apart from the removal of pharmaceuticals (Deegan et al. 2011), dyes (Regulska and Karpińska 2012; Regulska et al. 2013; Shang et al. 2011; Fan et al. 2011; Fischer et al. 2011), 
<smiles>CC(C)(Oc1ccc(CCNC(=O)c2ccc(Cl)cc2)cc1)C(=O)O</smiles>

Scheme 1 Chemical structure of bezafibrate

cyanides (Kabra et al. 2004), malodorous compounds (Kabra et al. 2004), fungicides (Topalov et al. 1999), herbicides (Topalov et al. 2000) and pesticides (Assalin et al. 2010), $\mathrm{TiO}_{2}$ was also satisfactorily applied in a destruction of bacteria, viruses (Henderson 2011) and cancer cells (Rozhkova et al. 2009). What is more, due to its photocatalytic activity, $\mathrm{TiO}_{2}$ was deeply researched in the field of self-cleaning (Sökmen et al. 2011), self-sterilizing (Hashimoto et al. 2005), highly hydrophilic and anti-fogging surfaces (Hashimoto et al. 2005). Another areas concerning the application of $\mathrm{TiO}_{2}$ include dye sensitized solar cells (Jiang et al. 2009), water splitting, $\mathrm{CO}_{2}$ photoreduction and the so-called 'synthesis by photons' (Arora et al. 2010).

$\mathrm{TiO}_{2}$ owns series of demanding features like low cost, chemical and biological inertness and non-toxicity. Unfortunately, only $3 \%$ of the solar radiation can be used to excite semiconductor molecules (Hashimoto et al. 2005). For this reason, many attempts have been done to enhance $\mathrm{TiO}_{2}$ activity (Pan et al. 2010). Among different approaches, including modifying $\mathrm{TiO}_{2}$ with charge-transfer catalysts, coating with photosensitizing dyes, noble metal deposition/coupling (Kundu et al. 2011; Zhang et al. 2009), metal doping and grafting, and modifying with polymers (Tomovska et al. 2011) or clays (Arora et al. 2010), carbonaceous nanomaterials (Kochuveedyu et al. 2011; Leary and Westwood 2011; Li et al. 2011; Wang et al. 2012a, 2012b; Yu et al. 2011; Zhang et al. 2011a, 2011b) seem to have the greatest potential. Due to this fact, we have decided to put an effort into preparing and applying a nanocomposite that consisted of titanium dioxide and a fullerene derivative $\left(\mathrm{C}_{60}\right)$, namely 2-(ferrocenyl)fulleropyrrolidine $\left(\mathrm{FcC}_{60}\right.$, Scheme 2). The second constituent of a nanocomposite is a covalentlylinked donor-acceptor dyad, which is composed of a fulleropyrrolidine directly linked to the ferrocene (Smith 2006).

So far, no attempts have been made to prepare and examine the above mentioned photocatalyst as a way of enhancing $\mathrm{TiO}_{2}$ photocatalytic activity. Therefore, it was described in the present paper. Moreover, the photodegradation process of BZF was studied with the aim of accessing the potential application of prepared photocatalyst in the pharmaceutical removal from the aquatic environment.

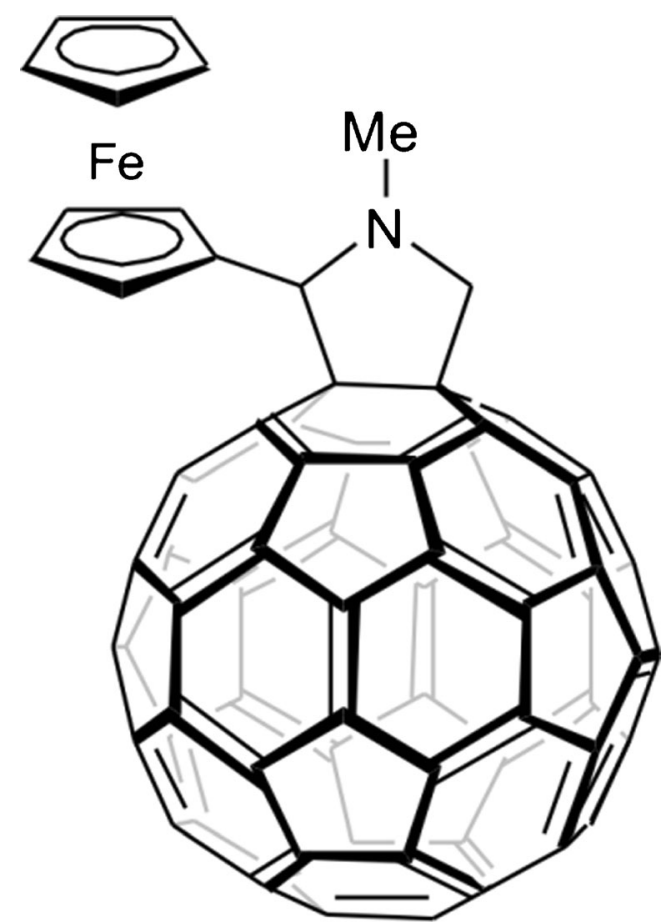

Scheme $2 \quad \mathrm{FcC}_{60}$ structure

\section{Materials and methods}

Materials $\mathrm{TiO}_{2}$ (anatase), bezafibrate, ferrocenaldehyd, sarcosin and anhydrous toluene were purchased from SigmaAldrich. 4-Chlorophenol (CP), 4-chlorobenzoic acid (CBA), 4-hydroxybenzaldehyde (HBD) (all Merck), absolute methanol, dipotassium hydrogen phosphate, orthophosphoric acid (all POCh, Gliwice, Poland) and ammonium reineckate (BDH Chemicals) were used. All above mentioned chemicals were of analytical grade reagents and used without further treatment. HPLC-grade acetonitrile was purchased from J.T. Baker. All solutions were prepared using deionized water, which was obtained by Polwater apparatus.

Apparatus Scanning electron microscopy was applied to investigate the morphology of the $\mathrm{FcC}_{60} / \mathrm{TiO}_{2}$ composite. Composite was imaged by secondary electron SEM with the use of an Inspect S50 scanning electron microscope from FEI. The accelerating voltage of the electron beam was $30 \mathrm{keV}$ and the working distance was $10 \mathrm{~mm}$. Differential scanning calorimetry (DSC) analyses were performed by a thermal analyzer DSC 1 (Mettler Toledo) with a heating rate of $10{ }^{\circ} \mathrm{C} / \mathrm{min}$ under air environment with flow rate $=200 \mathrm{~mL} / \mathrm{min}$. All runs were carried out from 0 to $500{ }^{\circ} \mathrm{C}$ and reverse cycles from 500 to $0{ }^{\circ} \mathrm{C}$ were registered too. The measurements were made in open aluminium crucibles, nitrogen was used as the purge gas in ambient mode, and calibration was performed using an indium standard. Attenuated total reflection infrared (ATRIR) spectra were recorded from 4,000 to $500 \mathrm{~cm}^{-1}$ using a Thermo Scientific Nicolet ${ }^{\mathrm{TM}} 6700$ spectrometer with 32 
accumulations at a resolution of $4 \mathrm{~cm}^{-1}$. This instrument was equipped with a $\mathrm{KBr}$ beamsplitter, an ETC source and a DTGS detector. Photolytic as well as photocatalytic degradation experiments were carried out in a solar simulator apparatus, namely SUNTEST CPS+ (Atlas, USA). The photon flux of solar simulated radiation was measured by chemical method-Reinecke's salt actinometer (Kuhn et al. 2004). The photon flux of solar simulated light of $250 \mathrm{~W} / \mathrm{m}^{2}$ was $2.18 \times$ $10^{-6}$ Einstein/s. The chromatographic experiments with HPLC-UV system were carried out on a Varian 920 liquid chromatograph using a quaternary solvent pump and an autosampler. The chromatographic column used Lichrospher ${ }^{\circledR} 100 \mathrm{RP}-18125 \times 4.6 \mathrm{~mm}$ packed with $5 \mu \mathrm{m}$ particle size. Separation was achieved using a linear gradient method. The mobile phase consisted of two solutions namely $\mathrm{A}$ and $\mathrm{B}$. Solution A was prepared from $10 \mathrm{mmol} / \mathrm{L}$ disodium hydrogen phosphate, $\mathrm{pH}$ adjusted to 7.4 with orthophosphoric acid, whereas solution $B$ was acetonitrile. The initial ratio of A:B was $70: 30(v / v)$. The gradient was as follows: 0 min, $70 \%$ A; $15 \mathrm{~min}, 70 \% \mathrm{~A} ; 25 \mathrm{~min}, 20 \% \mathrm{~A} ; 30 \mathrm{~min}, 20 \% \mathrm{~A}$; and $35 \mathrm{~min}, 70 \% \mathrm{~A}$. The column was equilibrated for $10 \mathrm{~min}$ before performing the next injection. The flow rate of the mobile phase was $1 \mathrm{~mL} / \mathrm{min}$ and the injection volume was $100 \mu \mathrm{L}$. The column was maintained at a room temperature. The eluent was monitored at $226 \mathrm{~nm}$. UV spectrophotometric analyses were performed in a Hitachi U-2800A UV-Vis spectrophotometer equipped with a double monochromator and double beam optical system (190-700 nm). UV studies were done using a 1-cm quartz cell. Absorbance was recorded in the range of 190-400 $\mathrm{nm}$, and the maximum absorption wavelength experimentally registered at $\lambda=226 \mathrm{~nm}$ was used for the calibration curve and further concentration measurements.

Photocatalyst preparation $\mathrm{FcC}_{60}$ was synthesized according to the following procedure. A solution of $100 \mathrm{mg}$ of $\mathrm{C}_{60}$, $60 \mathrm{mg}$ of ferrocene aldehyde and $25 \mathrm{mg}$ of N-methyl glycine in $100 \mathrm{~mL}$ of toluene was stirred at reflux temperature overnight. The solvent was removed in vacuum. The solid residue was purified by flash chromatography using toluene as an eluent affording $81 \mathrm{mg}(21 \%) .{ }^{1} \mathrm{H}$ NMR $(400 \mathrm{MHz}$, $\left.\mathrm{CDCl}_{3}: \mathrm{CS}_{2}=1: 1 v / v\right) \delta 3.05(\mathrm{~s}, 3 \mathrm{H}), 4.20(\mathrm{~m}, 1 \mathrm{H}), 4.21$ $(\mathrm{m}, 1 \mathrm{H}), 4.26(\mathrm{~m}, 1 \mathrm{H}), 4.28(\mathrm{~s}, 1 \mathrm{H}), 4.30(\mathrm{~s}, 4 \mathrm{H}), 4.48$ $(\mathrm{m}, 1 \mathrm{H}), 4.49(\mathrm{~s}, 1 \mathrm{H}), 4.58(\mathrm{~m}, 1 \mathrm{H}), 4.84(\mathrm{~m}, 1 \mathrm{H}), 4.88$ $(\mathrm{s}, 1 \mathrm{H})$, and $4.91(\mathrm{~s}, 1 \mathrm{H}) ;{ }^{13} \mathrm{C} \mathrm{NMR}(100 \mathrm{MHz}$, $\left.\mathrm{CDCl}_{3}: \mathrm{CS}_{2}=1: 1 v / v\right)$ 41.76, 67.02, 67.12, 67.56, 68.21, $69.31,70.95,77.00,141.82,142.37$, and 145.67.

$\mathrm{FcC}_{60} / \mathrm{TiO}_{2}$ nanocomposite was prepared by evaporationdrying method (Yao et al. 2008), previously applied to prepare carbon nanotubes- $\mathrm{TiO}_{2}$ nanocomposites. $\mathrm{FcC}_{60} / \mathrm{TiO}_{2}$ composite was made at 1:20 mass ratio of $\mathrm{FcC}_{60}$ to $\mathrm{TiO}_{2}$.

Photocatalytic degradation experiment The photocatalytic degradation experiments were performed in a $50-\mathrm{mL}$ glass cell. The reaction mixture consisted of $20 \mathrm{~mL}$ of BZF sample $\left(5 \times 10^{-5} \mathrm{~mol} / \mathrm{L}\right)$ and the photocatalyst $(1.6 \mathrm{~g} / \mathrm{L})$. The pharmaceutical-catalyst suspension was kept in the dark with
Fig. 1 SEM images of $\mathrm{FcC}_{60}$ / $\mathrm{TiO}_{2}$ in the mass ratios of $1: 1(a)$, 1:10 (b), 1:20(c) and $\mathrm{TiO}_{2}(d)$
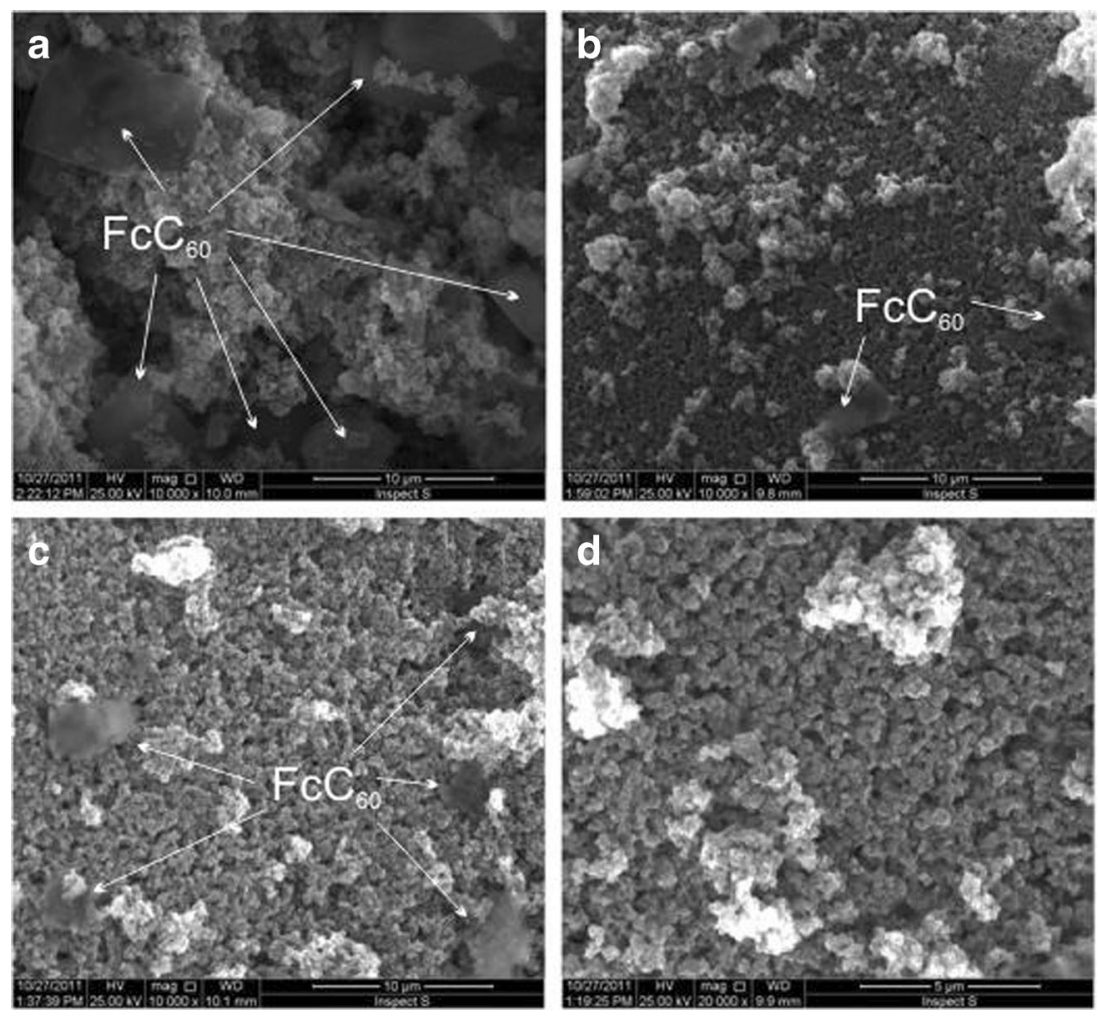


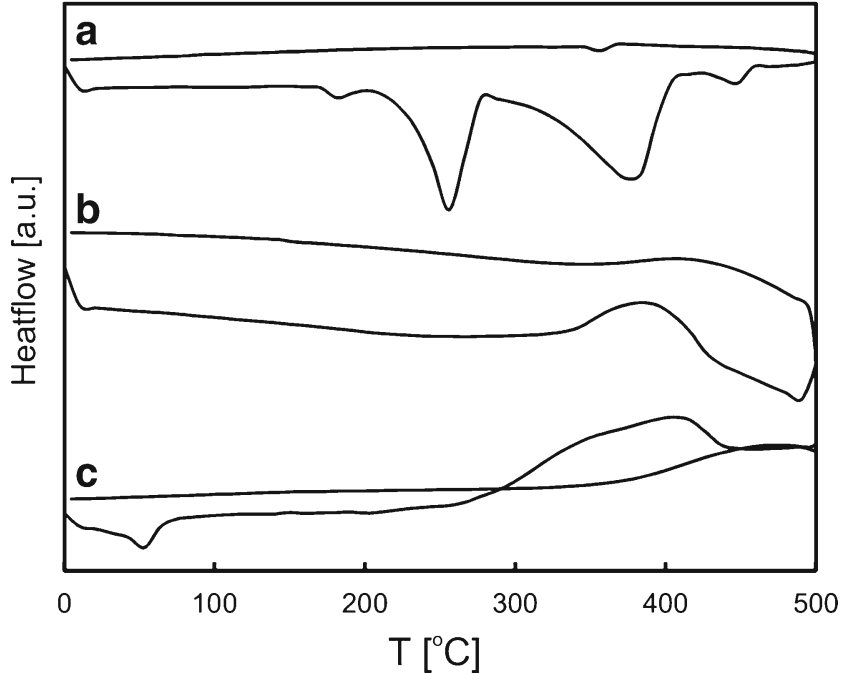

Fig. 2 DSC curves of BZF (a), $\mathrm{FcC}_{60} / \mathrm{TiO}_{2}(b)$ and $\mathrm{FcC}_{60} / \mathrm{TiO}_{2}$ after adsorption of BZF (c)

stirring for $1 \mathrm{~h}$ to ensure an adsorption-desorption equilibrium prior to the irradiation experiment. Such prepared mixture was subjected to irradiation by simulated sunlight for $120 \mathrm{~min}$. To determine the BZF degradation, the samples were collected at regular intervals $(10 \mathrm{~min})$ and centrifuged to remove the photocatalyst and the spectra of the obtained solution were recorded.

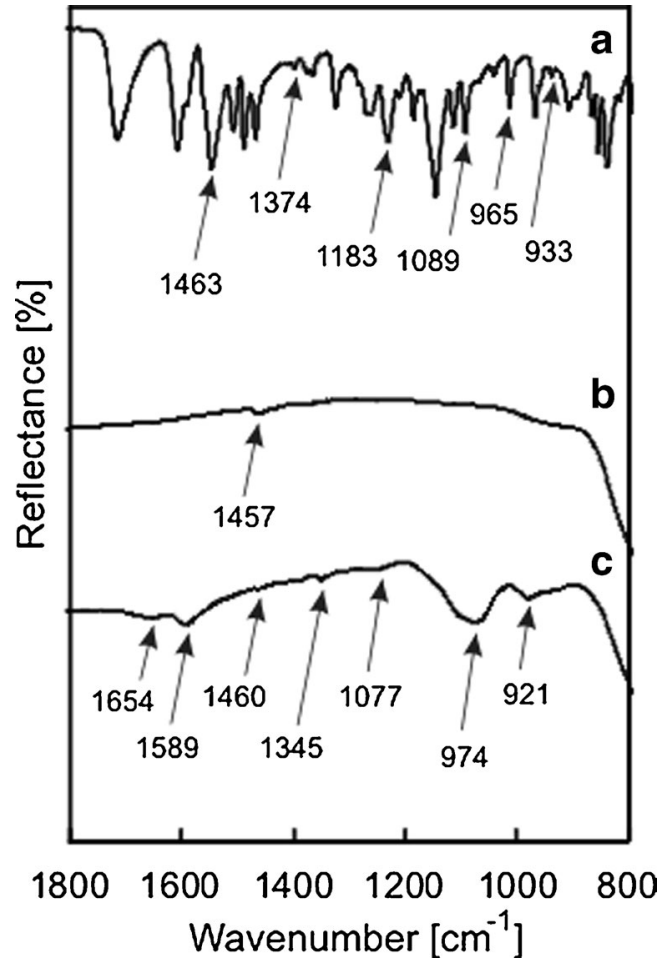

Fig. 3 ATR-IR spectra of BZF $(a), \mathrm{FcC}_{60} / \mathrm{TiO}_{2}(b)$ and $\mathrm{FcC}_{60} / \mathrm{TiO}_{2}$ after adsorption of BZF (c)

\section{Results and discussion}

The characterization of synthesized composite was done before photocatalysis experiments. For this purpose scanning electron microscopy, DSC and ATR-IR spectrometry were used.

Scanning electron microscopy was employed to investigate the morphology of the prepared $\mathrm{FcC}_{60} / \mathrm{TiO}_{2}$ composite. SEM images of pristine $\mathrm{TiO}_{2}$ and composites of different mass ratios $(1: 1,1: 10$ and $1: 20)$ of $\mathrm{FcC}_{60}$ to $\mathrm{TiO}_{2}$ were presented in Fig. 1. They show the presence of both components of the prepared material. The larger flakes with a smooth surface correspond to the $\mathrm{FcC}_{60}$ while the smaller particles to the $\mathrm{TiO}_{2}$. The proportions of smooth flakes to the smaller particles on presented pictures are in agreement with the mass ratios of $\mathrm{FcC}_{60}$ to $\mathrm{TiO}_{2}$ in the prepared composites. It can be seen that the greater the amount of $\mathrm{TiO}_{2}$ was introduced, the smaller smooth surface is present in the image. It can be attributed to the coverage of carbonaceous surface by $\mathrm{TiO}_{2}$ particles.

DSC curves of $\mathrm{BZF}, \mathrm{FcC}_{60} / \mathrm{TiO}_{2}$ and $\mathrm{FcC}_{60} / \mathrm{TiO}_{2}$ after adsorption of BZF were registered (Fig. 2). The DSC curve of BZF showed a sharp endothermic peak at $187^{\circ} \mathrm{C}$, which is typical for crystalline form $\alpha$ of that pharmaceutical
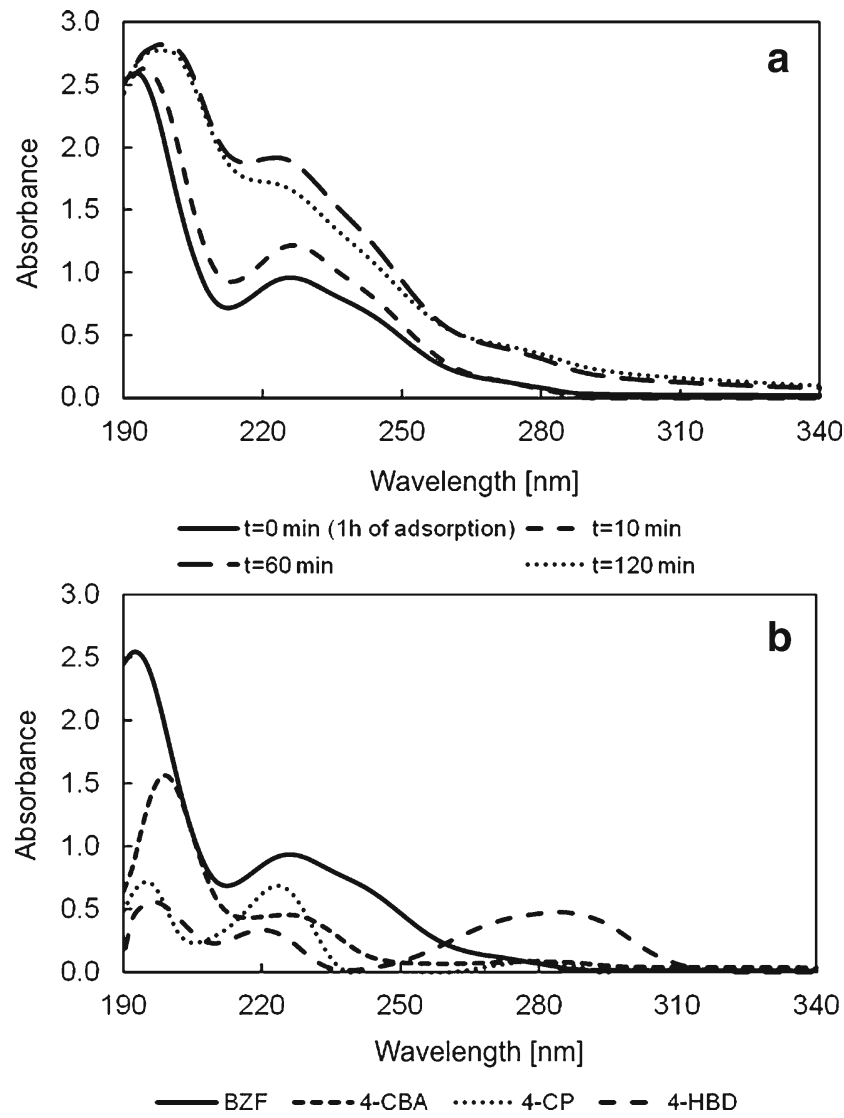

Fig. 4 Spectra of BZF before $(t=0 \mathrm{~min})$ and after photocatalysis $(t=10$, 60, $120 \mathrm{~min}$ ) (a). UV absorbance spectra of BZF, 4-CBA, 4-CP and 4HBD (b). $B Z F$ bezafibrate, 4- $C B A$ 4-chlorobenzoic acid, 4- $C P$ 4chlorophenol, 4-HBD 4-hydroxybanzaldehyde 


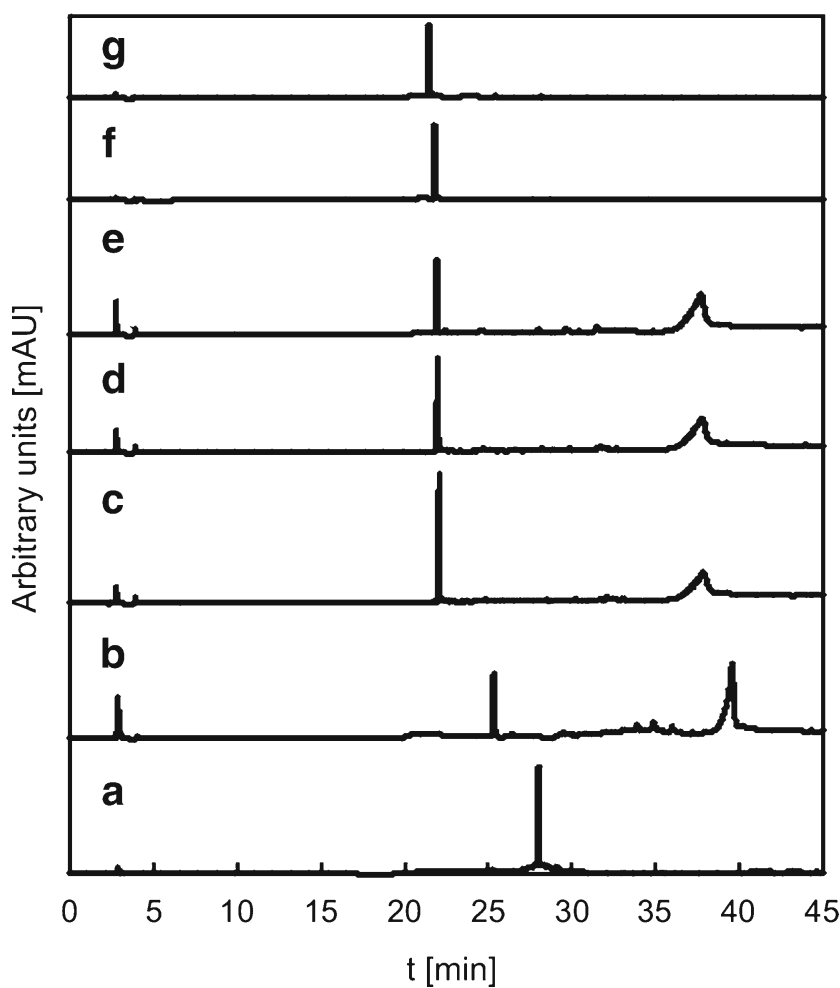

Fig. 5 Chromatograms of BZF before irradiation $(a)$ and after $10(b)$ and 120 min of photolysis $(c)$ as well as photocatalysis with application of both $\mathrm{TiO}_{2}(d 10 \mathrm{~min}, e 120 \mathrm{~min})$ and $\mathrm{FcC}_{60} / \mathrm{TiO}_{2}(f 10 \mathrm{~min}, g 120 \mathrm{~min})$

(Lemmerer et al. 2009). BZF does not show any crystallization exotherms upon cooling. However, above mentioned peak representing BZF melting is not observed on the DSC curve of $\mathrm{FcC}_{60} / \mathrm{TiO}_{2}$ after adsorption of $\mathrm{BZF}$ without further irradiation. Therefore, the DSC curve of $\mathrm{FcC}_{60} / \mathrm{TiO}_{2}$ after adsorption of BZF differs from the DSC curve of a bare $\mathrm{FcC}_{60} / \mathrm{TiO}_{2}$. That indicates the modification of the photocatalyst surface as a consequence of a pharmaceutical adsorption. It should be mentioned, that the major changes between the first and the third curve may be a consequence of the different values of heat flow in $\mathrm{FcC}_{60} / \mathrm{TiO}_{2}$ and $\mathrm{BZF}$. Photocatalyst is resistant to temperature influence in applied temperature ranges.

ATR-IR spectra of $\mathrm{BZF}, \mathrm{FcC}_{60} / \mathrm{TiO}_{2}$ and $\mathrm{FcC}_{60} / \mathrm{TiO}_{2}$ after adsorption of BZF were compared and presented in Fig. 3. Spectra were presented in the range of wavelengths in which the biggest differences were observed. After adsorption of BZF on the $\mathrm{FcC}_{60} / \mathrm{TiO}_{2}$ surface certain bands, namely at 1,589, 1,077, 974 and $921 \mathrm{~cm}^{-1}$, appeared. The band at $1,589 \mathrm{~cm}^{-1}$ was ascribed to the $\mathrm{N}-\mathrm{H}$ bending vibration $\nu_{\mathrm{N}-\mathrm{H}}$ of secondary amines, while the band at $1,077 \mathrm{~cm}^{-1}$ was assigned to the stretching vibrations of the bond between the aromatic carbon and chlorine $\left(\mathrm{C}_{\mathrm{Ar}-\mathrm{Cl}}\right)$ as well as to that of the ether group $\mathrm{C}-\mathrm{O}-\mathrm{C}$. Those results confirm modification of the photocatalyst surface after the adsorption of BZF.

UV spectrophotometry was applied to monitor the absorbance changes during irradiation of $\mathrm{BZF}$ in $\mathrm{FcC}_{60} / \mathrm{TiO}_{2}$ suspension with solar simulated light. An increase in the absorbance values was observed (Fig. 4a). However, no additional peaks were found in the registered spectra. This fact suggests that BZF does not undergo mineralization or its decomposition with the creation of photoproducts which absorb at the same UV region takes place.

HPLC analysis was used to confirm above assumption. Chromatograms of BZF before irradiation and after 10 and 120 min of photolysis (a-c in Fig. 5), as well as photocatalysis with application of both $\mathrm{TiO}_{2}$ (d and e in Fig. 5) and $\mathrm{FcC}_{60} /$ $\mathrm{TiO}_{2}$ photocatalysts (f and $\mathrm{g}$ in Fig. 5), were recorded and compared.

The obtained chromatograms proved that BZF undergoes photodegradation upon solar simulated light with the use of $\mathrm{FcC}_{60} / \mathrm{TiO}_{2}$ as well as $\mathrm{TiO}_{2}$ alone. $\mathrm{FcC}_{60} / \mathrm{TiO}_{2}$ nanocomposite was found to be more efficient photocatalyst than bare $\mathrm{TiO}_{2}$. In solutions with the presence of $\mathrm{FcC}_{60} / \mathrm{TiO}_{2}$ after only $10 \mathrm{~min}$ of irradiation remained only the one final photodegradation product $\left(t_{\mathrm{r}}=22.0\right)$. During photocatalytic decomposition of BZF with $\mathrm{TiO}_{2}$ application even after $2 \mathrm{~h}$ of exposure to the solar simulated light still remained four pharmaceutical degradation products. Compounds with their retention times detected by HPLC method were presented in Table 1. Three products of photocatalytic decomposition of BZF were identified using standard references. The obtained results are in agreement with the mechanism of BZF photodegradation proposed by Lambropoulou et al. (2008). Those compounds include 4-hydroxybanzaldehyde (4-HBD), 4-chlorophenol (4$\mathrm{CP})$ and 4-chlorobenzoic acid (4-CBA). This outcome explains why no changes were observed in the spectra registered during photocatalytic experiments after irradiation. It was

Table 1 Identified compounds by HPLC analysis

\begin{tabular}{|c|c|c|c|c|c|}
\hline Compound & Name & $\begin{array}{l}\text { Retention time } \\
{[\mathrm{min}]}\end{array}$ & $\begin{array}{l}\text { Photolysis } \\
(120 \text { min })\end{array}$ & $\begin{array}{l}\text { Photocatalysis }\left(\mathrm{TiO}_{2}\right) \\
(120 \mathrm{~min})\end{array}$ & $\begin{array}{l}\text { Photocatalysis }\left(\mathrm{FcC}_{60} / \mathrm{TiO}_{2}\right) \\
(120 \mathrm{~min})\end{array}$ \\
\hline 1 & $\begin{array}{l}\text { 4-Hydroxybanzal- } \\
\text { dehyde }\end{array}$ & 4.0 & + & + & - \\
\hline 2 & 4-Chlorophenol & 22.0 & + & + & + \\
\hline 3 & Bezafibrate & 27.7 & - & - & - \\
\hline 4 & 4-Chlorobenzoic acid & 37.7 & + & + & - \\
\hline
\end{tabular}


found that spectra of identified photodegradation products and bezafibrate are strongly overlapped (Fig. 4b). The increase in amount of generated photoproducts resulted in the increase of absorbance of final mixture. What is more, those compounds have higher absorption coefficients; therefore, during irradiation in the photocatalyst presence, increase in the absorbance is observed.

\section{Conclusions}

The efficiency of photocatalytic activity of newly synthesized composite was proved. BZF was found to undergo complete decomposition with the application of both $\mathrm{TiO}_{2}$ and $\mathrm{FcC}_{60} /$ $\mathrm{TiO}_{2}$. It was noticed that in the presence of $\mathrm{FcC}_{60} / \mathrm{TiO}_{2}$ bezafibrate is quickly transformed into 4-CP instead of three (4-HBD, 4-CP, 4-CBA) in case of photolytic and photocatalytic degradation with the application of bare $\mathrm{TiO}_{2}$.

Conducted experiments confirmed photocatalytic ability of $\mathrm{FcC}_{60} / \mathrm{TiO}_{2}$ composite. What is more, prepared photocatalyst showed higher catalytic activity than sole $\mathrm{TiO}_{2}$. Therefore, we believe that huge potential lies in composites that are based on carbonaceous nanomaterials and $\mathrm{TiO}_{2}$ as new efficient photocatalysts. Prepared composite could potentially be used in the decontamination of other organic pollutants from water. Heterogeneous catalysis was proved to have a huge potential as a new route of a destruction of undesired compounds present in the environment. However, the photocatalyst application should be preceded by preliminary studies concerning an identification of degradation products and an assessment of their toxicity.

Acknowledgments This work was financially supported by the National Science Centre, Poland (project 2012/05/N/ST5/01479).

The authors thank Dr. Marta E. Plonska-Brzezinska for SEM measurements. DSC, IR spectrometer and SEM were funded by EU, as part of the Operational Programme Development of Eastern Poland 2007-2013, project Nr POPW.01.03.00-20-034/09-00.

Open Access This article is distributed under the terms of the Creative Commons Attribution License which permits any use, distribution, and reproduction in any medium, provided the original author(s) and the source are credited.

\section{References}

Arora H, Doty C, Yuan Y, Boyle J, Petras K, Rabatic B, Paunesku T, Woloschak G (2010) Titanium dioxide nanocomposites. In: Challa S, Kumar SR (eds) Nanomaterials for the life sciences, Vol. 8. WILEY-VCH, Weinheim, pp 1-41

Assalin MR, de Moraes SG, Queiroz SN, Ferracini VL, Duran N (2010) Studies on degradation of glyphosate by several oxidative chemical processes: ozonation, photolysis and heterogeneous photocatalysis. J Environ Sci Health B 45:89-94
Calamari D, Zuccato E, Castiglioni S, Bagnati R, Fanelli R (2003) Strategic survey of therapeutic drugs in the Rivers Po and Lambro in Northern Italy. Environ Sci Technol 37:1241-1248

Castiglioni S, Bagnati R, Calamari D, Fanelli R, Zuccato E (2005) A multiresidue analytical method using solid-phase extraction and high-pressure liquid chromatography tandem mass spectrometry to measure pharmaceuticals of different therapeutic classes in urban wastewaters. J Chromatogr A 1092:206-215

Dantasa RF, Canterinob M, Marottab R, Sansa C, Esplugasa S, Andreozzi $R$ (2007) Bezafibrate removal by means of ozonation: primary intermediates, kinetics, and toxicity assessment. Water Res 41:2525-2532

Deegan AM, Shaik B, Nolan K, Urell K, Oelgemöller M, Tobin J, Morrissey A (2011) Treatment options for wastewater effluents from pharmaceutical companies. Int J Environ Sci Technol 8:649-666

Fan H-J, Lu C-S, Lee W-LW, Chiou M-R, Chen C-C (2011) Mechanistic pathways differences between $\mathrm{P} 25-\mathrm{TiO}(2)$ and $\mathrm{Pt}-\mathrm{TiO}(2)$ mediated CV photodegradation. J Hazard Mater 185:227-235

Fischer AR, Werner P, Goss K-U (2011) Photodegradation of malachite green and malachite green carbinol under irradiation with different wavelength ranges. Chemosphere 82:210-214

Godfrey E, Woessner WW, Benotti MJ (2007) Pharmaceuticals in on-site sewage effluent and ground water, western Montana. Ground Water 45:263-271

Hashimoto K, Irie H, Fujishima A (2005) $\mathrm{TiO}_{2}$ photocatalysis: a historical overview and future prospects. Jpn J Appl Phys 44:8269-8285

Henderson MA (2011) A surface science perspective on $\mathrm{TiO}_{2}$ photocatalysis. Surf Sci Rep 66:185-297

Hirsch R, Ternes T, Haberer K, Kratz K-L (1999) Occurrence of antibiotics in the aquatic environment. Sci Total Environ 225:109-118

Jiang K-J, Manseki K, Yu Y-H, Masaki N, Suzuki K, Song Y, Yanagida S (2009) Photovoltaics based on hybridization of effective dyesensitized titanium oxide and hole-conductive polymer P3HT. Adv Funct Mater 19:2481-2485

Kabra K, Chaudhary R, Sawhney RL (2004) Treatment of hazardous organic and inorganic compounds through aqueous-phase photocatalysis: a review. Ind Eng Chem Res 43:7683-7696

Kochuveedyu ST, Jang YJ, Jang YH, Cha M-A, Shin H, Yoon S, Lee S-S, Kim SO, Shin K, Steinhart M, Kim DH (2011) Visible-light active nanohybrid $\mathrm{TiO}_{2} /$ carbon photocatalysts with programmed morphology by direct carbonization of block copolymer templates. Green Chem 13:3397-3405

Kosma I, Lambropoulou DA, Albanis TA (2007) Determination of pharmaceutical compounds in water samples by solid-phase extraction (SPE) and gas chromatography-mass spectrometry, Proceedings of the 10th International Conference on Environmental Science and Technology, Kos Island, Greece

Kuhn HJ, Braslavsky SE, Schmidt R (2004) Chemical actinometry. Pure Appl Chem 76:2105-2146

Kundu S, Kafizas A, Hyett G, Mills A, Darr JA, Parkin IP (2011) An investigation into the effect of thickness of titanium dioxide and gold-silver nanoparticle titanium dioxide composite thin-films on photocatalytic activity and photo-induced oxygen production in a sacrificial system. J Mater Chem 21:6854-6863

Kunkel U, Radke M (2008) Biodegradation of acidic pharmaceuticals in bed sediments: insight from a laboratory experiment. Environ Sci Technol 42:7273-7279

Lambropoulou DA, Hernando MD, Konstantinou IK, Thurmanb EM, Ferrer I, Albanis TA, Fernández-Alba AR (2008) Identification of photocatalytic degradation products of bezafibrate in $\mathrm{TiO}(2)$ aqueous suspensions by liquid and gas chromatography. J Chromatogr A $1183: 38-48$

Leary R, Westwood A (2011) Carbonaceous nanomaterials for the enhancement of $\mathrm{TiO}_{2}$ photocatalysis. Carbon 49:741-772

Lemmerer A, Báthori NB, Esterhuysen C, Bourne SA, Caira MR (2009) Concomitant polymorphs of the antihyperlipoproteinemic Bezafibrate. Cryst Growth Des 9:2646-2655 
Li X, Qin Y, Picraux ST, Guo Z-X (2011) Noncovalent assembly of carbon nanotube-inorganic hybrids. J Mater Chem 21: $7527-7547$

Nikolaou A, Meric S, Fatta D (2007) Occurrence patterns of pharmaceuticals in water and wastewater environments. Anal Bioanal Chem 387:1225-1234

Pan H, Dou H, Xiong Z, Xu C, Ma J, Zhao XS (2010) Porous photocatalysts for advanced water purifications. J Mater Chem 20: $4512-4528$

Razavi B, Song W, Cooper WJ, Greaves J, Jeong J (2009) Free-radicalinduced oxidative and reductive degradation of fibrate pharmaceuticals: kinetic studies and degradation mechanism. J Phys Chem A 113:1287-1294

Regulska E, Karpińska J (2012) Photocatalytic degradation of olanzapine in aqueous and river waters suspension of titanium dioxide. Appl Catal B Environ 117-118:96-104

Regulska E, Bruś DM, Karpińska J (2013) Photocatalytic decolourization of direct yellow 9 on titanium and zinc oxides. Int J Photoenergy 2013:1-9

Rozhkova EA, Ulasov I, Lai B, Dimitrijevic NM, Lesniak MS, Rajh T (2009) A high-performance nanobio photocatalyst for targeted brain cancer therapy. Nano Lett 9:3337-3342

Shang J, Zhang Y, Zhu T, Wang Q, Song H (2011) The promoted photoelectrocatalytic degradation of rhodamine $\mathrm{B}$ over $\mathrm{TiO}_{2}$ thin film under the half-wave pulsed direct current. Appl Catal B Environ 102:464-469

Smith PM (2006) Studies on electron and energy transfer in porphyrin and fullerene based systems. $\mathrm{PhD}$ thesis, Wichita State University (USA)

Sökmen Tİ, Breen C, Clegg F, Buruk CK, Sivlim T, Akkan Ș (2011) A new nano- $\mathrm{TiO}_{2}$ immobilized biodegradable polymer with selfcleaning properties. Hazard Mater 187:199-20

Ternes TA (1998) Occurrence of drugs in German sewage treatment plants and rivers. Water Res 32:3245-3260

Ternes T (2006) Pharmaceuticals and metabolites as contaminants of the aquatic environment - an overview. Div Environ Chem Am Chem Soc 40:98-100, Reprints of Extended Abstracts

Ternes TA, Meisenheimer M, McDowell D, Sacher F, Jurgenbrauch H, Tehaist-Gulde B, Preuss G, Wilme U, Zulei-Seibert N (2002)
Removal of pharmaceuticals during drinking water treatment. Environ Sci Technol 36:3855-3863

Tomovska R, Daniloska V, Asua JM (2011) UV/Vis photocatalytic functionalization of $\mathrm{TiO}_{2}$ nanoparticle surfaces toward water repellent properties. J Mater Chem 21:17492-17497

Topalov A, Molnar-Gabor D, Csanadi J (1999) Photocatalytic oxidation of the fungicide metalaxyl dissolved in water over $\mathrm{TiO}_{2}$. Water Res 33:1371-1376

Topalov A, Molnar-Gabor D, Kosanic M, Abramovic B (2000) Photomineralization of the herbicide mecoprop dissolved in water sensitized by $\mathrm{TiO}_{2}$. Water Res 34:1473-1478

Wang Z, Huang B, Dai Y, Liu Y, Zhang X, Qin X, Wang J, Zheng Z, Cheng H (2012a) Crystal facets controlled synthesis of graphene@ $\mathrm{TiO}_{2}$ nanocomposites by a one-pot hydrothermal process. CrystEngComm 14:1687-1692

Wang D-H, Jia L, Wu X-L, Lu L-Q, Xu A-W (2012b) One-step hydrothermal synthesis of $\mathrm{N}$-doped $\mathrm{TiO}_{2} / \mathrm{C}$ nanocomposites with high visible light photocatalytic activity. Nanoscale 4:576-584

Weston A, Caminada D, Galicia H, Fent K (2009) Effects of lipidlowering pharmaceuticals bezafibrate and clofibric acid on lipid metabolism in fathead minnow (Pimephales promelas). Environ Toxicol Chem 28:2648-2655

Yao Y, Li G, Ciston S, Lueptow RM, Gray KA (2008) Photoreactive $\mathrm{TiO}_{2} /$ carbon nanotube composites: synthesis and reactivity. Environ Sci Technol 42:4952-4957

Yu J, Ma T, Liu S (2011) Enhanced photocatalytic activity of mesoporous $\mathrm{TiO}_{2}$ aggregates by embedding carbon nanotubes as electrontransfer channel. Phys Chem Chem Phys 13:3491-3501

Zhang H, Chen G, Bahnemann DW (2009) Photoelectrocatalytic materials for environmental applications. J Mater Chem 19:5089-5121

Zhang J, Xiong Z, Zhao XS (2011a) Graphene-metal-oxide composites for the degradation of dyes under visible light irradiation. J Mater Chem 21:3634-3640

Zhang P, Shao C, Zhang Z, Zhang M, Mu J, Guo Z, Liu Y (2011b) $\mathrm{TiO}_{2} @$ carbon core/shell nanofibers: controllable preparation and enhanced visible photocatalytic properties. Nanoscale 3:2943-2949

Zwiener C (2007) Occurrence and analysis of pharmaceuticals and their transformation products in drinking water treatment. Anal Bioanal Chem 387:1159-1162 